In the obese patients on total starvation, free fatty acids were considerably raised without any variation throughout the day. Increase of free fatty acids during fasting in both obese and lean patients has been reported by Bloom et al. (1966). A fall in plasma insulin to a mean of $8.3 \mu \mathrm{u} . / \mathrm{ml}$. during eight days' fasting in normal non-obese subjects was recorded by Cahill et al. (1966). The raised levels still present in our own obese patients suggest that the response to starvation may be different between lean and obese subjects.

Treatment with diguanide drugs is known to result in a reduction in body weight of obese diabetic patients (Patel and Stowers, 1964 ; Schwartz et al., 1966). Clarke and Duncan (1968), in a carefully controlled long-term prospective study, found that most diabetic patients gained weight when taking chlorpropamide and tended to lose weight on metformin therapy. This is in keeping with our findings (Hadden et al., 1962), where the mean change in weight in 150 patients treated for nine months or more with chlorpropamide was $+5.8 \mathrm{lb}$. $(+2.6 \mathrm{~kg}$.). Nevertheless, there is no doubt that careful attention to diet will enable a satisfactory weight to be maintained regardless of additional sulphonylurea therapy, as shown by the satisfactory weight reduction of the patients in the present series who were taking the sulphonylurea drugs.

We are grateful to our colleague Dr. J. A. Weaver for his permission to study some of these patients; to Mr. D. W. Neill, clinical biochemist, Royal Victoria Hospital, for laboratory facilities; and to Dr. B. D. M. Grassick, Hoechst Pharmaceuticals Ltd., and Dr. C. Boroda, Rona Laboratories, for advice and financial assistance. One of us (A. N. R.) was in receipt of a postgraduate scholarship from the Northern Ireland Hospitals Authority, which was later extended into a Royal Victoria Hospital Fellowship.

\section{REFERENCES}

Abramson, E.; and Arky, R. A. (1967). Metabolism, 16, 204

Bloom, W. L., Azar. G. and Clark, J. E. (1966). Metabolism, 15, 401. Cahill, G. F. et al. (1966). \%. clin. Invest., 45, 1751.

Chu, Ping-Chi, Conway, M. J., Krouse, H. A., and Goodner, C. J. (1968). Ann. intern. Med., 68, 757.

Clarke, B. F., and Duncan, L. I. P (1968). Lancet, 1, 123.

Danowski, T. S. (1967). Metabolism, 16, 865 .

Danowski, T. S. (1967). Metabolism, 16, 865. 9, 122

Duncombe, W. G. (1964). Clin. chim. Acta, 9, 122. Diabetes, 11,91 .

Hales, C. N., and Randle, P. J. (1963). Biochem. f., 88, 137.

Hoffman, W. S. (1937). \%. brol. Chem., 120, S1.

Karam, J. H., Grodsky, G. M., Pavlatos, F. C., and Forsham, P. H. (1965) Lancet, 1, 286.

Marble, A. (1965). Med. clin. N. Amer., 49, 1137.

Patel, D. P., and Stowers, J. M. (1964). Lancet, 2, 282.

Reaven, G., and Dray, J. (1967). Diabetes, 16, 487.

Schwartz, M. J., Mirsky, S., and Shaefer, L. E. (1966). Metabolism, 15, 808 .

Seltzer, H. S., Allen, E. W., Herron, A. L., jun., and Brennan, M. T. (1967). 9. clin. Invesi., 46, 323.

Sheldon, J., Taylor, K. W., and Anderson, J. (1966). Metabolism, 15, 874.

\title{
Measles Vaccination with Reduced Dosage
}

\author{
R. G. HENDRICKSE,* M.D., F.R.C.P.ED., M.R.C.P. ; D. MONTEFIORE,* M.D., M.C.PATH., DIP.BACT.
}

Brit. med. F., 1968, 4, 28-30

\begin{abstract}
Cummary : A field trial is reported in which good sero$\checkmark$ conversion rates were obtained when a dose of 200 TCID $_{50}$ Beckenham 31 strain (Wellcovax) measles vaccine was administered by Ped-O-Jet subcutaneously in a volume of $0.5 \mathrm{ml}$. per dose. It is suggested that use of this reduced dosage would lead to a significant reduction in the cost per dose of the vaccine, especially when administered on a scale large enough to justify the use of multidose containers.
\end{abstract}

\section{Introduction}

Widespread immunization against measles is currently being undertaken in several developing countries with outside financial assistance. The health authorities in these countries will eventually be faced with the problem of maintaining the immunity status of their child populations once the assisted schemes come to an end.

Measles vaccine is expensive even when administered to relatively large groups of children and multidose containers are used. Containers for single or small numbers of doses are relatively more expensive, since a fairly large proportion of the total cost is absorbed in ampouling. This high cost of measles vaccine is likely to present serious problems in many areas and may deter authorities from using the vaccine (Cooper et al., 1966). If adequate immunization was achieved with a lower dose of vaccine than is currently being used, there could be a significant reduction in the cost. It seemed worth while,

\footnotetext{
- Departments of Paediatrics and Medical Microbiology, University of Ibadan, Nigeria.
}

therefore, to investigate the immunizing potential of reduced doses of measles vaccine administered by the same technique and under similar field conditions to those obtaining in most countries where mass vaccination campaigns are currently in progress.

We report here the results of such a trial, which was undertaken in a rural area of Kwara State, Nigeria.

\section{Methods and Materials}

Vaccination was offered for children aged 6 months to 3 years ; in the event, a small number who were younger than these also attended, and there were also a few who were up to 4 years old.

Each child was registered, and a numbered card was completed giving its name, age, and sex; a duplicate numbered card was given to the parent bringing the child.

After registration the first 191 children had pre-vaccination blood samples taken: these were obtained by finger-prick, and the sample was absorbed on to numbered filter-paper discs which contained $0.2 \mathrm{ml}$. of blood when fully saturated. The rest of the children attending were vaccinated (see below) but no pre-vaccination blood samples were taken.

After vaccination each child was given a suitable dose of pyrimethamine to prevent any attack of malaria during the period when vaccination reactions might be expected, and was told to return to the clinic in four weeks' time, bringing the duplicate registration card. Post-vaccination finger-prick blood samples were taken from all children who had been bled initially 
and who returned for the second visit. Some additional postvaccination blood samples were obtained from children who were not bled initially.

\section{Vaccine and Administration}

Beckenham 31 strain measles vaccine (Wellcovax) was used. This was supplied as a lyophilized material of known viral content, which was reconstituted with distilled water immediately before the vaccination session began. Initial reconstitution yielded a suspension containing 1,000 TCID $_{50}$ virus per $0.5 \mathrm{ml}$. Further dilutions were made in distilled water to yield suspensions containing $330 \mathrm{TCID}_{50}$ and $200 \mathrm{TCID}_{50}$ per $0.5 \mathrm{ml}$. These dilutions were stored in a vacuum flask at $4^{\circ}$ C. until used. Bleeding and vaccinating the children took a little over four hours: at the end of the session the remaining vaccine dilutions were returned, at $4^{\circ} \mathrm{C}$., to the laboratory for check titration. They reached the laboratory about seven hours later, and were then frozen at $-40^{\circ} \mathrm{C}$. until titrated; the titration values obtained showed that there had been no loss in potency from the calculated values as a result of these procedures.

The first 140 children were given a dose of $200 \mathrm{TCID}_{50}$ virus, the next 29 received $330 \mathrm{TCID}_{51}$, and the next 22 received $1,000 \mathrm{TCID}_{50}$. The vaccine was given by Ped-O-Jet needleless injector subcutaneously into the buttock. The volume of each injection was $0.5 \mathrm{ml}$.

The remaining children were given vaccine of the same type (Beckenham 31), but from a different batch whose titre was not precisely known at the time. This was diluted to give an estimated $100 \mathrm{TCID}_{50}$ per $0.5-\mathrm{ml}$. dose ; titration of the remains of the vaccine showed that in fact each dose contained $160 \mathrm{TCID}_{50}$. Thirty-seven of these children who had not had pre-vaccination blood samples taken did have post-vaccination samples taken when they returned four weeks later.

\section{Vaccine Titrations}

These were carried out in BSC-1 green vervet kidney cells. Tubes were incubated for eight days at $36^{\circ} \mathrm{C}$. on roller drums.

\section{Serology}

Blood samples from the paper discs were eluted into $0.8 \mathrm{ml}$. of phosphate buffered saline. The assumption was made that each disc contained $0.2 \mathrm{ml}$. of blood, and that each blood consisted of $50 \%$ cells and $50 \%$ serum. Thus the resulting eluate was regarded as a $1: 10$ serum dilution. This was used, without heat inactivation, for the determination of neutralizing antibody content. The eluates were diluted in phosphate buffered saline, and an equal volume of phosphate buffered saline containing 30 to $100 \mathrm{TCID}_{50}$ measles virus was added to each dilution. The mixtures were incubated at room temperature for one hour, followed by four hours at $4^{\circ} \mathrm{C}$., after which $0.2 \mathrm{ml}$. of the mixture for each dilution step was added to each of two BSC-1 tissue-culture tubes. These were incubated at $36^{\circ} \mathrm{C}$. on roller drums, the results being read at five days.

\section{Results}

\section{Pre-vaccination Immunity}

Satisfactory pre-vaccination blood samples were obtained from a total of 182 children. Their immunity status, according to age groups, is shown in Table $I$.

It will be seen that over half the children were already immune to measles by the age of 3 years, and over half the children under 8 months old were also immune, in this case
TABLE I.-Pre-vaccination Immunity (182 Samples)

\begin{tabular}{c|c|c}
\hline Age in Months & No. Non-immune* & No. Immune \\
\hline $3-7$ & 14 & $15(51 \cdot 7 \%)$ \\
$8-12$ & 37 & $8(17.8 \%)$ \\
$13-24$ & 34 & $16(32.0 \%)$ \\
$25-36$ & 20 & $25(55.5 \%)$ \\
$37+$ & 2 & $11(84.6 \%)$ \\
\hline
\end{tabular}

* Children with neutralizing titres of less than 1:10 are regarded as non-immune.

probably largely due to the presence of maternal antibodies. The best age for measles vaccination in this community would therefore appear to be between 8 and 24 months of age.

\section{Post-vaccination Immunity}

Satisfactory paired blood samples were obtained from a total of 129 children. Details of the serological response to vaccination, according to age group and dose of vaccine, are given in Table II.

\begin{tabular}{|c|c|c|c|c|c|c|c|}
\hline Dose & $\begin{array}{c}\text { Age } \\
\text { in } \\
\text { Months }\end{array}$ & $\begin{array}{c}\text { Total } \\
\text { No. of } \\
\text { Paired } \\
\text { Sera }\end{array}$ & $\begin{array}{l}\text { Initially } \\
\text { Immune }\end{array}$ & $\begin{array}{c}\text { Initially } \\
\text { Non- } \\
\text { immune }\end{array}$ & $\begin{array}{c}\text { No. } \\
\text { Con- } \\
\text { verted* }\end{array}$ & $\begin{array}{c}\text { Conver- } \\
\text { sion } \\
\text { Rate } \\
(\%)\end{array}$ & $\begin{array}{c}\% \text { Immune } \\
\text { after } \\
\text { Vac- } \\
\text { cination }\end{array}$ \\
\hline$\stackrel{200}{\mathrm{TCID}_{50}}$ & $\begin{array}{c}3-7 \\
8-12 \\
13-24 \\
25+\end{array}$ & $\left.\begin{array}{l}19 \\
20 \\
24 \\
33\end{array}\right\} 77$ & $\left.\begin{array}{c}9 \\
4 \\
9 \\
23\end{array}\right\} 36$ & $\left.\begin{array}{l}10 \\
16 \\
15 \\
10\end{array}\right\} 41$ & $\left.\begin{array}{r}2 \\
15 \\
14 \\
8\end{array}\right\} 37$ & $\left.\begin{array}{l}20 \cdot 0 \\
93 \cdot 8 \\
93 \cdot 3 \\
80 \cdot 0\end{array}\right\} 90 \cdot 2$ & $\left.\begin{array}{l}57.9 \\
95 \cdot 0 \\
95.8 \\
93.9\end{array}\right\} 94 \cdot 8$ \\
\hline $\mathrm{TCID}_{\text {so }}$ & $\begin{array}{c}3-7 \\
8-12 \\
13-24 \\
25+\end{array}$ & $\left.\begin{array}{c}2 \\
5 \\
3 \\
13\end{array}\right\} 21$ & $\left.\begin{array}{l}1 \\
1 \\
2 \\
9\end{array}\right\} 12$ & $\left.\begin{array}{l}1 \\
4 \\
1 \\
4\end{array}\right\} 9$ & $\left.\begin{array}{l}1 \\
4 \\
1 \\
3\end{array}\right\} 8$ & $\left.\begin{array}{c}100 \\
100 \\
100 \\
75\end{array}\right\} 88 \cdot 9$ & {$\left[\begin{array}{c}100 \\
100 \\
100 \\
92 \cdot 3\end{array}\right\} 95 \cdot 2$} \\
\hline $\begin{array}{c}1,000 \\
\text { TCID }_{50}\end{array}$ & $\begin{array}{l}3-7 \\
8-12 \\
13-24 \\
25+\end{array}$ & $\left.\begin{array}{l}1 \\
3 \\
5 \\
1\end{array}\right\} 9$ & $\left.\frac{1}{2}\right\} 2$ & $\left.\begin{array}{l}3 \\
3 \\
1\end{array}\right\} 7$ & $\left.\begin{array}{l}-3 \\
3 \\
1\end{array}\right\} 7$ & $\left.\begin{array}{l}\overline{100} \\
100 \\
100\end{array}\right\} 100$ & $\left.\begin{array}{l}100 \\
100 \\
100 \\
100\end{array}\right\} 100$ \\
\hline
\end{tabular}

* Sero-conversion from a titre of less than $1: 10$, to a titre of $1: 40$ or greater. * Sero-conversion from a titre of less than $1: 10$, to a titre of $1: 40$ or greater.
The maiority of pust-vaccination titres were equal to or greater than $1: 160$, which The maiority of pust-vaccination
was the highest dilution tested.

There is an apparently low sero-conversion rate among the children aged 3 to 7 months given $200 \mathrm{TCID}_{50}$ virus. This is most probably due to a number of "non-converters" who appeared to be initially non-immune in fact, possessing titres of maternal antibodies which were too low to be detected by the laboratory methods used, but which were sufficient to inhibit multiplication of the vaccine virus.

The numbers of children in the 330 and $1,000 \mathrm{TCID}_{50}$ groups are very small, but if all age groups, with the exception of those aged 3 to 7 months, are combined, little difference is apparent in the serological responses to the differing dose levels.

Post-vaccination blood samples only were available from 37 of the children given $160 \mathrm{TCID}_{50}$ vaccine. The serological findings are given in Table III. Though the numbers are small there appears to be no significant difference in the proportion of children serologically immune four weeks after receiving any of the doses of vaccine used. This would suggest that serological conversion rates are satisfactory even with the lowest doses of vaccine used, and would thus indicate that there is a reasonable margin of safety with $200 \mathrm{TCID}_{50}$.

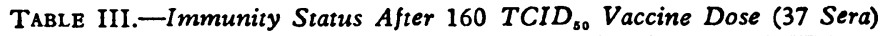

\begin{tabular}{|c|c|c|}
\hline Age in Months & No. Immune & No. Non-immune \\
\hline $\begin{array}{l}3-7 \\
8-12 \\
13-24 \\
25+\end{array}$ & $\begin{array}{r}\left.\begin{array}{r}4(66.7 \% \\
10(83.3 \%) \\
7(87.5 \%) \\
10(90.9 \%)\end{array}\right\} 27(87.1 \%)\end{array}$ & $\left.\begin{array}{l}2 \\
2 \\
1 \\
1\end{array}\right\} 1$ \\
\hline
\end{tabular}

\section{Discussion}

It is well known that small doses of attenuated or " further attenuated" measles virus can produce infection in susceptible individuals. Karelitz et al. (1961) showed that $100 \mathrm{TCID}_{30}$ of attenuated virus would give full sero-conversion rates. 
McCrumb et al. (1962) also showed that very small doses of vaccine virus, as assayed in tissue culture, would infect human subjects. Rey et al. (1965) obtained $95 \%$ sero-conversion rate with $100 \mathrm{TCID}_{50}$ of Schwartz further-attenuated vaccine, and Cooper et al. (1966) quote a personal communication from Dr. Schwartz indicating that as little as $10 \mathrm{TCID}_{50}$ of this vaccine, given by syringe and needle, will infect.

Hendrickse et al. (1966) noted that doses of approximately $30 \mathrm{TCID}_{50}$ of Leningrad 16 measles vaccine, as titrated in Hep- 2 cells, produced a $78 \%$ sero-conversion rate when given by syringe and needle to a small group of children. The same group of workers reported (Hendrickse et al., 1967) promising results when small doses of further-attenuated vaccine were given by Dermojet ; the disadvantage of this apparatus is that only about $0.07 \mathrm{ml}$. is delivered, and sometimes it is obvious that a substantial proportion of the dose remains on the skin. A similar observation was made by Calafiore et al. (1968), who showed that the efficacy of Schwartz vaccine was dependent not only on the dose administered in terms of $\mathrm{TCID}_{50}$ content but also on the volume of fluid in which the virus was injected. These workers suggested that small infective doses might be satisfactory when given in a relatively large volume, but that until this had been demonstrated $1,000 \mathrm{TCID}_{50}$ should be retained as the standard dose.

Markham (1962) also noted that low doses of measles vaccine would produce good sero-conversion rates, and felt that the main reason for having a $1,000 \mathrm{TCID}_{50}$ dose as standard was the relative instability of the fluid vaccine.

The stability of the reconstituted vaccine depends, however, not only on the nature of the virus itself but also on the stabilizers incorporated in the vaccine preparation during manufacture. The present work shows that, at least with the particular vaccine used, stability of the virus suspension, when used in low dosage, need not be a problem. Good sero-conversion rates were obtained with a dose of $200 \mathrm{TCID}_{50}$ under field conditions, with the vaccine injected subcutaneously in a volume of $0.5 \mathrm{ml}$.

While it may be desirable to confirm these results with other vaccine preparations, it would seem that the way is open for a considerable reduction in the cost per dose of measles vaccine, especially when used on a scale large enough to justify the use of multidose containers.

We wish to thank the Permanent Secretary, Ministry of Health, Kwara State, for permission to carry out this study ; the management and medical staff at Bacita Sugar Estate for their co-operation, the use of their clinic facilities, and kind hospitality ; the Wellcome Research Laboratories for supplies of vaccine; Dr. M. Gurney, Alhaji S. Aderinto, Mr. A. Akinkunmi, and Mr. G. Coker, for their active participation in the trial; and Dr. M. Grisby (U.S.A.I.D.) for the loan of a Ped-O-Jet needleless injector.

\section{REFERENCES} Calafiore, D. C., Nader, P. R., Lepow, M. L., Nankervis, G. A., Casey,
H., and Warren, R. J. (1968). Amer. Y. Epidem., 87, 247. Cooper, C., Morley, D. C., Weeks, M. C., and Beale, A. J. (1966). Lancet, 1, 1076.

Hendrickse, R. G., Montefiore, D., Sherman, P., and Peradze, T. (1966). Brit. med. F., 1, 779 .

Hendrickse, R. G., Montefiore, D., and Sherman, P. (1967). Nigerian Med. Ass. (Western Branch) News Bull., 1, pp. 9-10.

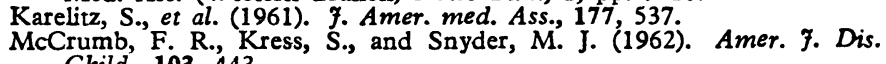
Child., 103, 443.

Markham, F. S. (1962). Amer. F. Dis. Child., 103, 437.

Rey, M., Baylet, R., Cantrelle, P., Dauchy, S., Diop Mar., I., and Guévin, M.' (1965). Bull. Soc. méd. Afr. noire Langue franç., 10, 392.

\title{
Dermatitis Herpetiformis in Two Patients with Idiopathic Steatorrhoea (Adult Coeliac Disease)
}

\author{
N. G. FRASER,* M.B., M.R.C.P.ED. ; ANNE FERGUSON, $†$ M.B., B.SC., M.R.C.P., M.R.C.P.GLASG. \\ D. MURRAY $\ddagger$ M.B., B.SC.
}

Brit. med.F., 1968, 4, 30-31

\begin{abstract}
Cummary: Two patients who had had idiopathic steatorrhoea for several years developed typical eruptions of dermatitis herpetiformis. In each case the rash responded to treatment with dapsone.

It is more usual for the rash to precede the enteropathy when the two occur together, but the association between coeliac disease and dermatitis herpetiformis is not yet clear.
\end{abstract}

\section{Introduction}

Dermatitis herpetiformis, one of the blistering group of skin diseases, is associated with histological abnormalities of the small intestine in about $70 \%$ of patients (Marks et al., 1966 ; Fraser et al., 1967 ; Fry et al., 1967 ; van Tongeren et al., 1967 ;

\footnotetext{
- Senior Registrar, University Department of Dermatology, Western Infirmary, Glasgow W.1.

† Lecturer, University Department of Medicine, Glasgow Royal Infirm-

₹ Lecturer, University Department of Pathology, Glasgow Royal Infirmary.
}

Marks et al., 1968). The malabsorption state which may accompany this intestinal abnormality is generally mild, but troublesome diarrhoea, weight loss, and anaemia can occur. Thus upset in intestinal structure and function has previously been shown only in patients who had already developed the rash of dermatitis herpetiformis, though a history of diarrhoea antedating the rash has been reported in some patients (Fraser et al., 1967 ; Marks et al., 1968).

In the following two cases diagnosed initially as idiopathic steatorrhoea the typical eruption of dermatitis herpetiformis developed after several years.

\section{Case 1}

This patient was first admitted to Glasgow Royal Infirmary in December 1956, at the age of 52 years, for investigation of anaemia. The presenting symptoms were tiredness and exertional dyspnoea. There were no symptoms referable to the gastrointestinal tract. Treatment with folic acid had been given before admission. 